\title{
Policy Issues in Enhancing the Output Of Agribusiness Small And Medium Scale Piggery Enterprises (AGRI-SMEs) in Abia State
}

\author{
Onwumere $\mathbf{J}$. \\ Department of Agribusiness and Management, \\ Michael Okpara University of Agriculture, \\ Umudike. P.M.B 7267, Umuahia, Abia State, Nigeria. \\ Email: meetjoe64@yahoo.com
}

\begin{abstract}
The need for this study was rooted on the worrisome state of Agri-SMEs which has not responded positively despite government programmes, incentives and supportive services of research and extension. Bende agricultural zone of Abia state which has 12 local government areas in it was purposively chosen because of the presence of the State ADP, Ministry of Agriculture, National Root Crops Research Institute and University of Agriculture in it. Through random sampling, three Local Government Areas (L.G.As) comprising of Ikwuano, Umuahia North and South Local Government Areas were selected. Also, following a random sampling process, forty (40) agri-SMEs operators involved in piggery management were studied. They were selected from sampling frame of piggery operators provided by Local Government Area officials. The results presented in rank order of influence indicated that level of education and distance of operators to research and extension service centres were first and second factors hindering access to research and extension services in the area. Also, major factors affecting the output of operators included the education level, total cost of production and access to research and extension services. Therefore, policy considerations by the government should be directed towards achieving the universal basic education, bringing research and extension services sub-centres closer to the people and reducing total cost of production of agri-SME operators will immensely contribute to enhancement of output realization of piggery operators.
\end{abstract}

Key-words: Policy, Enhancing, Output, Accessibility, Piggery, Enterprises

\section{INTRODUCTION}

The survival of agribusiness small and medium scale enterprises (Agri-SMEs) in Nigeria depends on how one has perceived, planned, analysed, operated and managed the Agri-SMEs (Buchele, 1977). Records have shown that Agri-SMEs can be found everywhere in the society. They include agribusiness farm firms, fast food enterprises, lather enterprises, bakeries, fisheries, piggeries, poultries and the related firms. Piggery Agri-SMEs are those small and medium scale enterprises that are involved in primary production or processing or marketing of pigs (Swine) and its related products. The massive attention and support given to Agri-SMEs relate to the widely acclaimed fact that Agri-SMEs are major sources of employment just like the 
other non agribusiness small and medium enterprises. They have a higher capacity for generating employment in Nigeria than some large scale enterprises (CBN, 1990). Agri-SMEs are important as a major source of domestic capital formation via the mobilization and productive channeling of private savings. Because of Agri-SMEs significant roles in the local and national development and growth of various economies, they have aptly been referred to as "the engine of growth" and catalysts for socio-economic transformation of any country. Agri-SMEs represent veritable vehicles for the achievement of national economic objectives of employment generation and poverty reduction at low investment cost as well as the development of entrepreneur capabilities including indigenous technology. Agri-SMEs manifests itself as a process of increasing the employment choices available to individuals, through better extension services, education, training, health and nutrition and gainful employment (Onwumere et al, 2000, Olayide et.al,1981, Ojiambo,1995 and Madlay, 1995).

In recognition of the enormous potential roles of Agri-SMEs some of which have been outlined above, special measures and programmes have been designed and policies enunciated and executed by governments to encourage Agri-SMEs development in Nigeria. The measures are: fiscal and protective fiscal policies; specialized financial institutions and funding schemes; favourable tariff structure; Development of Agricultural Development Programmes (ADPs) and establishment of export processing zones.

Despite the incentives, policies, programmes, and support aimed at revamping the Agri-SMEs, they have performed rather below expectation in Nigeria. An average operator in Agri-SMEs always hinges his failure on poor access to finance and extension service. Some others argue on the issue of inappropriate management skills, difficulty in accessing global market, lack of entrepreneurial skills and knowhow, poor infrastructure, poor cash management and poor capital (Harper, 1984). Finance is usually considered as a major constraint of Agribusiness-SMEs, while this may be true, empirical evidences have shown that finance contributes only about 25 per cent to the success of Agri-SMEs. Thus, the operation of extension services, other appropriate support systems like extension education services and enabling environment are indispensable for better thriving of Agri-SMEs in Nigeria. (Onwumere et al 2000; Nigerian Business Info, 2006; and Akpabio, 2007).

The following research questions were asked in other to achieve the purpose of this work: what are the annual outputs of agri-SME piggery enterprises in the area? What factors affect output of agri-SME piggery enterprises? What factors affect the level of accessibility of agri-SME piggery enterprise investors to research and extension services available in the study area? What policies are necessary for greater output realization in the enterprise?

\section{Objectives of the Study}

The major objective of this study was to investigate the policy issues in enhancing the output of agribusiness small and medium scale piggery enterprises. The specific objectives are to:

- identify the annual outputs of agribusiness small and medium scale (agri-SME) piggery enterprises in the area,

- identify factors affecting their output, 
- analyse the level of accessibility and factors affecting piggery agri-SMEs accessibility to research and extension services, and

- compare the output of piggery agri-SMEs operators with access to research and extension services with those without access.

\section{METHODOLOGY}

The study was conducted in Bende agricultural zone of Abia State. Bende Agricultural zone was chosen because of the presence of major relevant agricultural institutions such as Michael Okpara University of Agriculture, Umudike, National Root Crops Research Institute, Abia State ADP and State Ministry of Agriculture Headquarters in the area. These institutions are vested with providing research and extension assistance to the various agribusinesses in the catchments areas of their operation.

A random sampling technique was adopted to select the small and medium scale piggery agribusinesses for the study. Also, from 12 Local Government Areas (L.G.As) in Bende agricultural zone, three L.G.As comprising of Umuahia North and South and Ikwuano Local Government Areas were selected because they were the closest areas to the afore mentioned agricultural institutions in the State. From the lists of piggery agri-SMEs available in the areas, 15 operators were selected from Umuahia north, another 15 from Umuahia south and 10 operators from Ikwuano L.G.As respectively. In all a total of 40 small and medium scale piggery agribusiness operators were investigated on the issue of annual output realization and accessibility to research and extension services to them.

The data collection was achieved through the use of structured questionnaire and interview schedule aimed at eliciting data on age, educational level, output level, years of entrepreneurial experience, distance of operators to research and extension service centres. Data analysis was done with the use of simple and efficient descriptive statistics (frequencies, percentages and tables) and rank method.

\section{RESULT AND DISCUSSION}

Socio-economic characteristics of the piggery agri-SME operators

Table (1) showed the socio-economic characteristics of the piggery operators. The males and females constitute $70 \%$ and $30 \%$ of the piggery agribusiness small and medium scale enterprise operators respectively. Further, $20 \%, 57.5 \%$ and $22.5 \%$ of the operators possessed a maximum of primary, secondary and tertiary education respectively. The socio-economic results showed a significant involvement of both sexes in the business. Also from the result, it can be inferred that few operators in the piggery business had tertiary education.

\section{Annual Output Realized by Piggery Agri-SME Operators}

About half $(50 \%)$ of the Piggery Agri-SMEs operators in the study area have output value ranging between $\mathrm{N} 500,000$ and $\mathrm{N} 900,000$. About $37.5 \%$ of the operators output value was less than N500, 000 , while, $12.5 \%$ had output value of $\mathrm{N} 1$ 000,000 and above (Table 2). These values indicate that an Agribusiness small and medium scale piggery enterprise is thriving well in the study area. 


\section{Factors Affecting Output of Output Piggery Agri-SME Operators}

The distribution of factors affecting the output of Agribusiness small and medium scale piggery enterprises is presented on Table 3 . The result revealed the percentages of influence of the factors affecting output as follows: educational level of operators $(75 \%)$, total cost of production $(72.5 \%)$, access to research and extension services $(70 \%)$. Others include firm size $(50 \%)$, income of entrepreneurs $(40 \%)$, years of entrepreneurial experiences $(30 \%)$ and age $(22.5 \%)$. The factors are presented and ranked according to the level of influence on piggery output as responded by the AgriSMEs piggery operators in the area. In all, the operators responded that education level of operators, total cost of production and access to research and extension services ranked as first, second and third factors affecting the output realization of the piggery operators in the study area. Moreover, farm size, income of entrepreneurs, years of entrepreneurial experience and age of operators ranked third, forth, fifth, sixth and seventh (Table 3). Akpabio, (2007), agreed that education of fisher folks in Nigeria will enhance their output performance.

\section{Levels of Accessibility to Research and Extension Services}

The distribution of piggery agri-business operators by level of accessibility to research and extension service from research and extension service institutions in the state are shown on Table (4). The result showed that $50 \%$ of piggery agri-SME operators had no contact with any research and extension institution in the study areas. Also, $30 \%$ and $20 \%$ of the operators claimed to have average contact (i.e once in a month contact annually) and regular contact respectively.

\section{Factors Affecting the Accessibility to Research and Extension Services}

The factors affecting the access of agribusiness small and medium scale piggery enterprises to research and extension service were ranked as follows: level of education of operators $(90 \%)$ distance of research and extension service unit to operators $(80 \%)$, level of output from investment $(75 \%)$, firm size $(65 \%)$ and years of entrepreneurial experience $(50 \%)$ (Table 5). By ranking distribution of these factors, education came first. This showed its relevance to useful information from the extension agents or the research and extension institutions, as it enhances skill.

\section{Analysis of Output of Piggery Agri-SME Operators with or Without Access to Research and Extension Services}

Comparative analysis of the output of the Agribusiness-piggery small and medium scale enterprises with and without access to research and extension services was carried out as shown on Table 6 below. It was observed that $37.5 \%, 50 \%$ and $18.5 \%$ of piggery-SMEs operators with access to extension services produced output

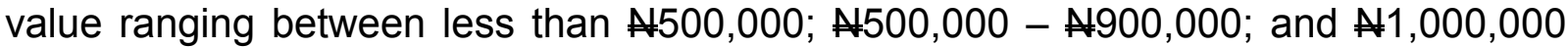
and above respectively. Whereas, $50 \%$ and $50 \%$ another of piggery-SMEs operators without access to extension services produced output ranging from less than $\mathbf{A} 500,000, \mathbf{N 5 0 0 , 0 0 0}-\mathbf{N} \mathbf{5 0 0 , 0 0 0}$ and none had $\mathbf{N 1}$ million and above. The result of the comparative analysis revealed that only the piggery-SMEs operators with access to research and extension services were able to produce output worth up to N1 million and above whereas their counterparts without access could not. This implied that 
access to research and extension services was an advantage since it set the beneficiaries at an edge over those that had not access.

\section{CONCLUSION}

Agribusiness small and medium scale piggery enterprise is a welcome business venture in the study area. This is so when one considers the output worth of the operators financially. Also, the participants in the enterprise involved both men and women which implied that the survival rate of the enterprise is high in the area. Policy statements to enhance the output of the piggery agri-SMEs operators were therefore suggested as follows: increased investment in education by governmental and nongovernmental organizations to enhance the literacy level of the operators; subsidy packages that will reduce the costs of inputs; location of sub-research and extension centres closer to interior areas of the agricultural zone to enhance access to these centres; extension agents should advice the operators on the need of investment diversification to increase their off farm income opportunities. This will reduce dependency on the farm income which in turn increases output. Also, the participation of youths should be encouraged as against the aged participation, since the aged population is associated with greater consumption rate, which reduces output realization. It therefore, implied that efforts to address educational problems; access to research and extension services, total cost of production, farm size, income of entrepreneurs, years of entrepreneurial experience, total output and age of operators will go a long way to enhance the output of operators.

TABLE 1: Distribution of respondents by socio-economic characteristics: $\mathbf{n}=\mathbf{4 0}$

\begin{tabular}{ccc}
\hline \multicolumn{1}{c}{ Item } & Frequency & Percentage (\%) \\
\hline Gender: & 28 & 70 \\
Male & 12 & 30 \\
Female & 40 & 100 \\
Total & & \\
Level of Education: & 8 & 20 \\
Primary & 23 & 57.5 \\
Secondary & 9 & 22.5 \\
Tertiary & 40 & 100 \\
Total & & \\
\hline
\end{tabular}

Source: Field survey 2007/2008 
TABLE 2: Distribution of piggery Agri-SMEs operators by annual output realized: $n=\mathbf{4 0}$

\begin{tabular}{lcc}
\hline \multicolumn{1}{c}{ Level of output(N) } & Frequency & Percentage (\%) \\
\hline Less than 500,000 & 15 & 37.5 \\
$500,000-900,000$ & 20 & 50 \\
$1,000,000$ and Above & 5 & 12.5 \\
\hline
\end{tabular}

Source: Field survey 2007/2008

TABLE 3: Distribution of factors affecting the output of Agribusiness SMEs Operators in Abia State: $\mathbf{n}=\mathbf{4 0}$

\begin{tabular}{lccc}
\hline \multicolumn{1}{c}{ Controlling factors } & $\begin{array}{c}\text { Multiple } \\
\text { response } \\
\text { frequency }\end{array}$ & $\begin{array}{c}\text { Percentage } \\
\mathbf{( \% )}\end{array}$ & Rank \\
\hline Educational level & 30 & 75 & 1 st \\
Total cost production & 29 & 72.5 & $2 \mathrm{nd}$ \\
Access to research \& Extension & 28 & 70 & $3 \mathrm{rd}$ \\
services & 20 & 50 & 4 th \\
Firm size & 16 & 40 & 5 th \\
Income of entrepreneurs & 12 & 30 & 6 th \\
Years of entrepreneurial & 9 & 22.5 & 7 th \\
experience & 9 & & \\
Age & &
\end{tabular}

Source: Field survey 2007/2008

TABLE 4: Distribution of respondent by extent of contact with extension services from research and extensions institutions: $n=\mathbf{4 0}$

\begin{tabular}{lccl}
\hline Nature of Access & Frequency & $\begin{array}{c}\text { Percentage } \\
\text { (\%) }\end{array}$ & Contact period \\
\hline No of contact at all & 20 & 50 & None \\
Average contact & 12 & 30 & $\begin{array}{l}\text { Once in two months } \\
\text { per annum }\end{array}$ \\
Regular contact & 8 & 20 & Monthly \\
\hline
\end{tabular}

Source: Field survey 2007/2008 
Journal of Agricultural Extension

Vol. 12 (2) December, 2008

TABLE 5: Rank distribution of factors affecting agribusiness SMEs operators access to extension services: $n=\mathbf{4 0}$

\begin{tabular}{|c|c|c|c|}
\hline Controlling factors & $\begin{array}{l}\text { Multiple Response } \\
\text { Frequency }\end{array}$ & $\begin{array}{c}\text { Percentage } \\
\text { (\%) }\end{array}$ & Rank \\
\hline Level of education & 18 & 90 & 1st \\
\hline $\begin{array}{l}\text { Distance to research \& } \\
\text { extension service unit } \\
\text { Level of output from }\end{array}$ & 16 & 80 & 2nd \\
\hline investment & 15 & 75 & $3 r d$ \\
\hline $\begin{array}{l}\text { Firm size } \\
\text { Years of entrepreneurial }\end{array}$ & 13 & 65 & 4th \\
\hline experience & 10 & 50 & 5th \\
\hline
\end{tabular}

Source: Field survey 2007/2008

TABLE 6: Comparative analyses of piggery agri-SMEs operators with and without access to research and extension services: $n=40$

\begin{tabular}{lcccccc}
\hline Level of output (=N=) & \multicolumn{2}{c}{$\begin{array}{c}\text { Total } \\
\text { frequency }\end{array}$} & \multicolumn{2}{c}{ With access } & \multicolumn{2}{c}{$\begin{array}{c}\text { Without } \\
\text { access }\end{array}$} \\
& Freq & $\%$ & $\begin{array}{c}\text { Freq } \\
\%\end{array}$ & Freq & $\%$ \\
Less than 500,000 & 15 & 37.5 & 5 & 24 & 10 & 50 \\
$500,000-900,000$ & 20 & 50 & 10 & 50 & 10 & 50 \\
1 million and above & 5 & 18.5 & 5 & 25 & 0 & 0 \\
Total & 40 & 100 & 20 & 100 & 20 & 100 \\
\hline
\end{tabular}

Source: Field survey 2007/2008

\section{References}

Akpabio, I.A., Okon, D.P., and Daniel, K. S., (2007),Perceived Training Needs of Fisher Folks in Akwa lbom State Nigeria (In) Agricultural Society of Nigeria Conference Proceedings 2006. pp $304-305$.

Buchele, R.B., (1997), the management of Business and Public Organizations; McGraw-Hill, Tokyo.

Central Bank of Nigeria (1990), First Annual Monetary Policy and Measurement;Macmillan Publishing Company, London.

Harper (1984). How Effective Are Credit Policies In Developing Countries, ELBS Publishers, London.

Madlay, J.C. (1995) Training in agriculture International; Agricultural Development. Pp $19-23$. 
Nigerian Business Info (2006). Prospects of Nigerian Agri-SMEs under the small and medium Industries Equity Investment Scheme (SMIEIS) Nigerian business Info volumes.

Ojiambo, J.B. (1995). Agricultural information system in Kenyaln: Aina et al (eds) Agricultural Information in Africa. Ibadan Third World Services Limited.

Olayide, S.O., Ogunfowora, O., Essang, S.M., and Idabacha, F. (1981), Elements of Rural Economics, Ibadan University Publishers pp 156 - 157.

Onwumere, J.U.J., Ige, C.S., (2000), Economic Development - Meaning Measurement and Relevance. Longman Publishers. 